\title{
The fossil fauna of Mazon Creek
}

\author{
Hans-Peter Schultze \\ Institut für Paläontologie, Museum für Naturkunde, Invalidenstr. 43, D-10115 Berlin, Germany
}

Keywords: Book review, Mazon Creek, fossil fauna

Review of: Richardson's Guide to the Fossil Fauna of Mazon Creek, edited by Charles W. Shabica \& Andrew A. Hay. Northeastern Illinois University, Chicago, Illinois, 1997: xviii +308 pp., 385 figs., 4 tables, 1 faunal list; $\$ 75.00$ (hard cover) ISBN 0-925065-21-8.

Since the last century, the area around Mazon Creek in northern Illinois, about $100 \mathrm{~km}$ southwest of Chicago, has been known for its Pennsylvanian fossils. Mainly plant fossils were found along Mazon Creek and in the open coal pits of that area until the 1950s. Langford $(1958,1963)$ was the first to give a compilation of the flora and fauna of Mazon Creek. He listed and figured 60 genera including 71 species of animal fossils. As the coal mining moved farther south, and Pit 11 was opened in the $1950 \mathrm{~s}$, the relationship between plant and animal fossils in the iron concretions drastically changed. In this new book, the number of animal genera recorded has increased three times over that of Langford (1963), omitting about another 130 insect genera.

The paleoenvironment of the Pit $\mathbf{1 1}$ area is considered to represent a coastal marine habitat (Essex fauna), whereas the old collecting areas north and farther east are considered freshwater (Braidwood fauna) (Johnson \& Richardson, 1966). The late Dr. Eugene S. Richardson, Jr., curator of invertebrates at the Field Museum in Chicago, focused his attentions on the new Mazon Creek locality Pit 11, from the 1950s to his death. He collected by himself, as well as with colleagues and students, and he organized with his students, but without success, a sys- tematic collecting effort that tried to match that of private collectors. Of great importance, however, was his connection to private collectors. This connection eriabled him to view all new finds and photograph them. His access to these collections was of importance to specialists because it provided them with material for a description of the diverse fauna. Richardson was able to motivate his colleagues to engage themselves in the Mazon Creek fossils, but he himself compiled mostly raw data and photographs. He could not finish the project, and Dr. Charles W. Shabica took over the compilation of the book after Richardson's death in 1983. Shabica enlisted 24 authors to write short articles for the book - an immense task to collect all these manuscripts. Therefore, the book took a long time to be published.

. The book itself contains $\mathbf{3 5}$ articles on different animal groups and 11 generalized articles. A chapter on the history of the coal mining industry in northern Illinois precedes the geology and paleontology sections. The mining of the Upper Pennsylvanian coal began with very unsafe underground mining around 1850 and then switched to large scale strip mining in the 1920s that extended up to 1976. Although no collecting took place on the talus dumps of the underground mines, the dumps of the open strip mines permitted a much larger access to the ironstone concretions than along the Mazon Creek.

Six chapters by Gordon Baird deal with the geological setting, distribution of the fossils, diagenetic processes and the paleoenvironment. He provides a detailed analysis of the paleoenvironmental data and demonstrates that the division between fresh- 
water (Braidwood) and marine (Essex) fauna introduced by Johnson \& Richardson (1966) is still the most reasonable interpretation. A better integration between these articles and some chapters on special groups would have avoided some contradictions, since preconceived ideas from the authors with regard to the life style of their creatures argue that these fossils were either washed down from fresh water or brought in from the sea by storms. First, one notices that nearly all described animal fossils here are from one area, Pit 11 (even though rarely cited throughout the book), which is clearly a coastal marine deposit. The high diversity would contradict any interpretation as brackish environment, which would be characterized by an impoverished fauna. Even Baird, however, demonstrates his own preconceived ideas in his faunal compilation, e.g., he places lungfish and xenacanths in the freshwater environment, despite the fact that the lungfish Conchopoma is known only from the marine Essex fauna (Pit 11) and the xenacanth teeth are from both environments. The latter "versatility" is the case too for many fishes and the snakelike amphibian Aornerpeton, which Baird figured in the freshwater environment; they are in fact either euryhaline, or as marine fishes able to enter the rivers.

The description of the remarkably diverse and extremely well-preserved fauna begins with the Cnidaria (chapter 6) and is followed upon by chapters on other marine groups, such as polychaete worms, nonannelid worms, and enteropneusts. The description of bivalves is very taxonomically oriented and includes a description of two new species. These last authors contradict all paleoenvironmental interpretational evidence and favor a salt marsh, marshy estuary, or tidal flat. All the other molluscs (polyplacophorans, gastropods, and cephalopods) are represented by marine forms. A coleoid with ten tentacles and double row of arm hooks is a special rarity of Pit 11 .

The arthropods form the main part of the Mazon Creek fauna. They occur in both biota, but with the insects more diverse in the Braidwood fauna. There are also horseshoe crabs, diverse arachnids, and crustaceans (Remipedia, Malacostraca, Phyllopoda, and Maxillopoda). Here one would have hoped for more precise information on localities of the described forms. For example, Baird uses "estheriids" as indicators of fresh water whereas the only figured one is from the marine deposits of Pit 11. The most diverse arthropod group of Mazon Creek are the insects; unfortunately they are represented in the book by only a few forms. The author provides a shallow plea for foregiveness with a citation at the beginning of the article, and the following paper deals with a general theme, the origin of insect wings and insect metamorphosis as evidenced by Mazon Creek insects (KukalovaPeck). The Mazon Creek eurypterid is characterized as exclusively freshwater dwelling, even though it occurs in both faunas. Other arthropods (euthycarcinoids and thylacocephalans) and onychophorans are known from Pit 11 only.

A few chonetoids and inarticulate brachiopods, and echinoderms (a holothurian and one crinoid specimen) are also known only from Pit 11. The body shape of the holothurian is visible and they have a calcareous preserved mouth ring.

The vertebrates are divided into three chapters. Pit 11 has furnished very unique specimens of modern agnathans without hard skeleton: a myxinoid and a petromyzontid, besides some other more questionable agnathans. Typical for the fish fauna are the specimens of juveniles and even coelacanths with yolk sacks. Only the chondrichthyans of Pit 11 are presented, and the xenacanths known from the Braidwood and Essex faunas are not mentioned. The tetrapod fauna is represented by what was earlier named Lepospondyli (Aistopoda, Nectridea, Microsauria and Lysorophia), two temnospondyl taxa, and one captorhinomorph reptile. The specimens demonstrate the imprint of the body and in some cases external gills.

Two chapters describe problematica and coprolites. The Tully Monster known through various specimens has not yet been placed definitively into a major group of the animal kingdom. It has eyes that sit laterally on a bar on each side of the body, and a long proboscis with a toothed "claw". It may be the most famous fossil of Mazon Creek (Pit 11).

Of use at the end of the book is the listing of all genera and species in traditional classification (except for 130-150 insect genera). The insects are listed partly, not including Richardson's insects (Richardson, 1956). The list of Mazon Creek 
fossils named in honour of collectors is incomplete; for instance, it does not even include all the species named in honour of Richardson (e.g., Mazoscolopendra richardsoni, and Euphemites richardsoni).

Fossils are extremely well preserved in the Mazon Creek ironstone concretions. Fossils preserved with such fine details require an excellent reproduction, and it is unfortunate that the photographs are so badly processed. One can only imagine what is shown on some of the photographs with aid of the accompanying drawing. One can compare old photos in Langford (1963: e.g., figs. 153 and 163) with those of the same specimens in the new book (figs. 14A.7 and 14A.24) and note the regrettable differences; even the photos in the poorly presented book on Mazon Creek by Nitecki (1979) are better. It is a pity because Richardson went to extremes to get superior photographs of each specimen. In contrast, the drawings are good and very informative.

The book, nevertheless, gives a complete overview of the fauna of an outstanding Lagerstätte. Most fossils are documented with photos and drawings. That gives an extensive presentation of Late Pennsylvanian fossils for paleontologists and fossil collectors. Researchers of Lagerstätten will need this book to find here the data of one compiled and interpreted locality. Compilations of Late Pennsylvanian Lagerstätten with less diverse faunas have recently been published (Mapes \& Mapes, 1989; Zidek, 1992; Poplin \& Heyler, 1994). Thus, the publication of the fauna of Mazon Creek was long overdue.

\section{References}

Johnson, R.G. \& E.S. Richardson Jr, 1966. A remarkable Pennsylvanian fauna from the Mazon Creek area, Illinois. J. Geol, 74: 626-631.

Langford, G., 1958. The Wilmington coal flora from a Pennsylvanian deposit in Will County, Illinois: 1-360 (ESCONI, Downers Grove, Illinois).

Langford, G., 1963. The Wilmington coal fauna and additions to the Wilmington coal flora from a Pennsylvanian deposit in Will County, Illinois: 1-200 (ESCONI, Downers Grove, Illinois).

Mapes, G. \& R. Mapes (eds.), 1989. Regional geology and paleontology of upper Paleozoic Hamilton quarry area in southeastern Kansas. Kansas Geol. Surv. Guidebook, Ser. 6 [for 1988]: 1-273.

Niteckì, M.H. (ed.), 1979. Mazon Creek fossils: i-xv, 1-581 (Academic Press, New York/London).

Poplin, C. \& D. Heyler (eds.), 1994. Quand le Massif central étaít sous l'équateur. Un écosystème carbonifere à Montceau-les-Mines. Ministère Ensign. supérieur Rech., Com. Trav. hist. scient., Sect. Sci., Mém., 12: 1-331.

Richardson, E.S., Jr., 1956. Pennsylvanian invertebrates of the Mazon Creek area, Illinois. Insects. Fieldiana Geology, 12: 15-56.

Zidek, J. (ed.), 1992. Geology and paleontology of the Kinney Brick Quarry, Late Pennsylvanian, central New Mexico. N. Mexico Bur. Mines Miner. Resources, Bull., 138: i-v, 1-142.

Received: 29 April 1998 